\title{
Disulfiram inhibits epithelial-mesenchymal transition through TGF $\beta$-ERK- Snail pathway independently of Smad4 to decrease oral squamous cell carcinoma metastasis [Corrigendum]
}

$\mathrm{Bu}$ W, Wang Z, Meng L, et al. Cancer Manag Res. 2019;11:3887-3898.

The authors have advised that because of Jilin University's rule that each paper can have only one first author and can't have co-first authors, they want to make a change in the author list. As a result, in the affiliations section the asterisks should be removed from the author names Wenhuan $\mathrm{Bu}$, Zilin Wang and Lin Meng and the sentence "*These authors contributed equally to this work" should also be removed.

\section{Publish your work in this journal}

Cancer Management and Research is an international, peer-reviewed open access journal focusing on cancer research and the optimal use of preventative and integrated treatment interventions to achieve improved outcomes, enhanced survival and quality of life for the cancer patient.
The manuscript management system is completely online and includes a very quick and fair peer-review system, which is all easy to use. Visit http://www.dovepress.com/testimonials.php to read real quotes from published authors. 